\title{
Quantitative Research on the Impact of Opening to the Outside World on Industrial Competitiveness from the Perspective of Intelligent Data Analysis -Taking Guangzhou as an Example
}

\author{
Author: Zhong Jiayi ${ }^{1, *}$ \\ ${ }^{1}$ Guangzhou College of Technology and Business, Guangzhou, Guangdong 510850, China
}

\begin{abstract}
Intelligent data analysis can use statistics, big data and other data analysis tools to discover the internal connections between transactions from the data. Use the relevant principles of intelligent data analysis to quantitatively study the relationship between Guangzhou' s total import and export value, foreign direct investment and industrial development. Quantitative research shows that foreign direct investment is of great has a significance to the improvement of Guangzhou's industrial competitiveness, especially the development of the tertiary industry. Although the impact of import and export on Guangzhou's industrial competitiveness is not as significant as foreign direct investment, the impact must not be ignored. On the basis of quantitative research results, it is proposed that Guangzhou should continue to make breakthroughs in optimizing the foreign investment environment, vigorously developing the producer service industry, and increasing the opening up of high-end manufacturing industries to promote the formation of a new pattern of comprehensive opening up.
\end{abstract}

\section{INTRODUCTION}

Promoting reform and development through opening up is an important driving force for the continuous new achievements of the Chinese economy. At present, China's economy has entered a stage of high-quality development, and opening up to the outside world at a higher level is the only way for China's economy to realize the conversion of new and old kinetic energy and enhance international competitiveness. As the frontier of China's reform and opening up, Guangzhou has a high degree of economic openness. It needs to take the lead in setting an example in the new round of major opportunities for China to expand and open up, promote reform, drive innovation, and promote development through opening up to achieve industrial transformation and upgrading. This article empirically studies the relationship between Guangzhou's opening to the outside world and industrial competitiveness through quantitative analysis methods, and provides certain theoretical support for Guangzhou's economy to inject new impetus, add new momentum, add new vitality, and expand new space.

As far as the industrial competitiveness of a region is concerned, there are many influencing factors, such as total import and export trade, foreign direct investment, R\&D funding, patent applications and authorizations, government policies, etc. These factors can affect the industrial competitiveness of the region to a certain extent.
The key is to use data analysis methods and determine which factors play a major role in the improvement of industrial competitiveness. Only on this basis can the policy recommendations made be more targeted.

\section{RESEARCH STATUS}

Scholars at home and abroad have carried out a lot of fruitful research on the relationship between opening up and industrial development. De Leeuw et al and Ren et al, based on the study of the European Union, believe that industrial agglomeration is an important reason for promoting regional economic development ${ }^{[1-2]}$. Rodrik et al. demonstrated through empirical analysis that foreign trade has played a certain role in promoting the upgrading and upgrading of Chinese products ${ }^{[3]}$. Based on sample data from various regions in China, Tian Yinhua et al. found that the upgrading of industrial structure can promote economic growth through empirical tests ${ }^{[4]}$. Huang Qingbo and others believe that opening to the outside world is generally conducive to promoting the transformation and upgrading of the industrial structure ${ }^{[5]}$. $\mathrm{Fu}$ Qiang's research also confirmed that the increase in the degree of opening to the outside world can promote the upgrading of domestic industrial structure, and then promote economic development ${ }^{[6]}$. Zhang Liguang et al. pointed out that trade opening can promote industrial development by promoting capital inflow, technological progress, and total factor productivity ${ }^{[7]}$. From the 
perspective of industrial flow, labor flow, trade flow, etc., Zhao Wei believes that China's regional economy has obvious characteristics of internationalization and internal opening, and proposed the concept of "dual opening" ${ }^{[8]}$. Konan et al. (2004) empirically proved that the opening of the production service industry has a significant positive effect on downstream manufacturing enterprises in developing countries ${ }^{[9]}$. Ishikawa et al. found that when the restrictions on the opening up of the service industry are relaxed, the welfare effect will turn from negative to positive ${ }^{[10]}$.

The research results at this stage show that opening to the outside world, especially a high level of opening to the outside world, has a significant role in promoting the development of a country's industrial competitiveness, and can achieve industrial agglomeration and promote industrial production efficiency.

\section{AN EMPIRICAL ANALYSIS OF OPENING LEVEL AND INDUSTRIAL COMPETITIVENESS}

\subsection{Variable selection}

This paper chooses the total value of Guangzhou's imports and exports and the amount of foreign investment actually used as the representative variables of the degree of opening-up, represented by TIEV and FDI, respectively; the output value of the secondary industry and the tertiary industry are used as the representative variables of industrial competitiveness, using SIV and TIV representative. The data comes from the Guangzhou Statistical Yearbook over the years, and the time span is from 2008 to 2019, a total of 12 years. Taking into account the possible heteroscedasticity of time series data and eliminating the influence of dimensions to a certain extent, this paper will logarithmize all data and record them as LOG (TIEV), LOG (FDI), LOG (SIV), LOG(TIV).

\subsection{Trend description of each variable}

From 2008 to 2019, the total import and export value of Guangzhou increased from 568.6 billion yuan to 1000.4 billion yuan, an average annual increase of about $5 \%$; the actual use of foreign investment increased from 25.16 billion yuan to 49.28 billion yuan, an average annual increase of about $6 \%$; The output value of the secondary industry increased from 327.5 billion yuan to 645.4 billion yuan, an average annual increase of about $6 \%$; the output value of the tertiary industry increased from 493.614 billion yuan to 169.2322 billion yuan, an average annual increase of about $11 \%$. Guangzhou opened to the outside world The level and industrial competitiveness have achieved rapid improvement. As shown in Figure 1.

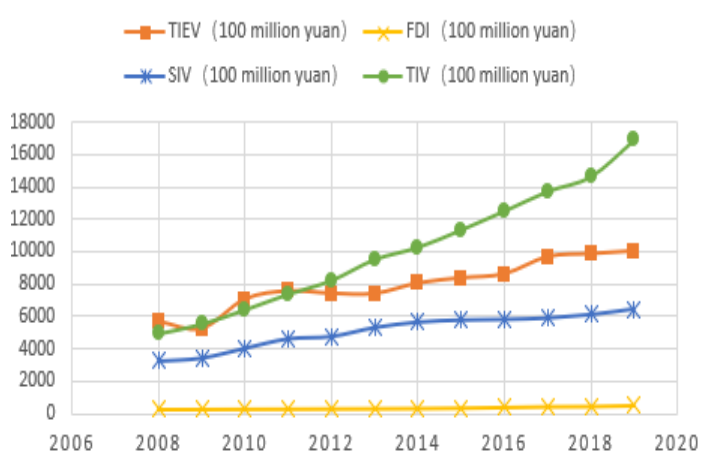

Figure 1 The opening-up level and the trend of industrial competitiveness development in Guangzhou (2008-2019)

\subsection{Correlation analysis between variables}

Using statistical analysis software, the correlation coefficients among TIEV, FDI, SIV, and TIV can be obtained, as shown in Table 1. The correlation coefficient between TIEV and FDI is 0.9218 , which shows that foreign direct investment can greatly promote the development of foreign trade. Compared with SIV, the correlation coefficient between TIEV and TIV is higher at 0.9541 , which shows that the competitiveness of the service industry is more benefited from the increase in foreign trade. The correlation coefficient between FDI and TIV is the highest at 0.9756 . The foreign-invested economy is the backbone of the rapid development of Guangzhou's service industry.

Table 1 Correlation coefficient table among various variables

\begin{tabular}{lllll}
\hline Correlation & TIEV & FDI & SIV & TIV \\
coefficient & & & + \\
\hline TIEV & 1 & - & -1 & - \\
FDI & 0.921868 & 1 & -1 & \\
SIV & 0.942751 & 0.856664 & 1 & \\
TIV & 0.954117 & 0.97566 & 0.946926 & 1 \\
\hline
\end{tabular}

\subsection{Build a linear equation}

According to the relevant principles of economic measurement, the linear equations between $\log (\mathrm{TIEV})$, $\log (\mathrm{FDI})$ and $\log (\mathrm{SIV}), \log (\mathrm{TIV})$ can be established respectively, such as formula (1), formula (2), and formula (3), As shown in formula (4), the relevant statistical results of the fitting equation are shown in Table 2. 
Table 2 Fitting equation test result table

\begin{tabular}{|c|c|c|c|c|c|c|c|c|c|}
\hline \multirow[b]{2}{*}{$\begin{array}{c}\text { Fitting } \\
\text { equatio } \\
n\end{array}$} & \multicolumn{3}{|c|}{ Intercept } & \multicolumn{3}{|c|}{$\mathrm{X}$ Variable } & \multirow[b]{2}{*}{ F value } & \multirow[b]{2}{*}{$\mathrm{R}^{2}$} & \multirow[b]{2}{*}{$\operatorname{Adj} R^{2}$} \\
\hline & $\begin{array}{l}\text { Coeffi } \\
\text { cients }\end{array}$ & $\begin{array}{c}\text { Standa } \\
\text { rd } \\
\text { error }\end{array}$ & $t$ Stat & $\begin{array}{l}\text { Coeff } \\
\text { cients }\end{array}$ & $\begin{array}{c}\text { Standa } \\
\text { rd } \\
\text { error }\end{array}$ & t Stat & & & \\
\hline $\begin{array}{l}\text { Fomul } \\
\text { a (1) }\end{array}$ & $\begin{array}{l}-0.40 \\
937\end{array}$ & $\begin{array}{l}0.442 \\
238\end{array}$ & $\begin{array}{c}-0.92 \\
568\end{array}$ & $\begin{array}{l}1.055 \\
995\end{array}$ & $\begin{array}{c}0.113 \\
669\end{array}$ & $\begin{array}{c}9.290 \\
117\end{array}$ & 86.31 & 0.8962 & 0.8858 \\
\hline $\begin{array}{l}\text { Fomul } \\
\text { a (2) }\end{array}$ & $\begin{array}{c}1.534 \\
961\end{array}$ & $\begin{array}{l}0.411 \\
699\end{array}$ & $\begin{array}{c}3.728 \\
36\end{array}$ & $\begin{array}{l}0.859 \\
864\end{array}$ & $\begin{array}{c}0.163 \\
539\end{array}$ & $\begin{array}{l}5.257 \\
845\end{array}$ & 27.64 & 0.7343 & 0.708 \\
\hline $\begin{array}{l}\text { Fomul } \\
\text { a (3) }\end{array}$ & $\begin{array}{c}-3.28 \\
374\end{array}$ & $\begin{array}{l}0.732 \\
854\end{array}$ & $\begin{array}{c}-4.48 \\
075\end{array}$ & $\begin{array}{r}1.866 \\
282\end{array}$ & $\begin{array}{c}0.188 \\
366\end{array}$ & $\begin{array}{r}9.907 \\
752\end{array}$ & 98.164 & 0.908 & 0.898 \\
\hline $\begin{array}{l}\text { Fomul } \\
\text { a (4) }\end{array}$ & $\begin{array}{c}-0.25 \\
143\end{array}$ & $\begin{array}{c}0.422 \\
832\end{array}$ & $\begin{array}{l}-0.59 \\
463\end{array}$ & $\begin{array}{l}1.680 \\
228\end{array}$ & 0.167 & $\begin{array}{r}10.00 \\
363\end{array}$ & $\begin{array}{c}100.07 \\
2\end{array}$ & 0.909 & 0.900 \\
\hline
\end{tabular}

The coefficients of the intercept term in Equation 1 and Equation 4 are not significant, so they are discarded. Overall, the goodness of fit of Equation 3 and Equation 4 is better than that of Equation 1 and Equation 2. The $\mathrm{R}^{2}$ of Equation 4 is 0.909 and the F statistic is 100.07 , which is the best fitting effect among the four equations. It can be seen that, compared with the tertiary industry, the tertiary industry is most affected by the opening-up policy, especially the foreign investment policy. Therefore, the government must fully consider its impact on the competitiveness of the tertiary industry when formulating policies related to opening up. In addition, from the general law of economic development, as the level of economic development increases, the tertiary industry will develop faster than the secondary industry, indicating that the economic structure is continuously optimized and upgraded. At the same time, we must also consider the positive relationship between foreign trade and the improvement of industrial competitiveness, and promote the transformation and upgrading of Guangzhou's industry in both the quantity and quality of foreign trade.

\section{POLICY SUGGESTION}

From the results of empirical analysis, it can be seen that the competitiveness of Guangzhou's industry, especially the competitiveness of the tertiary industry, is more affected by the opening-up policy. Compared with total foreign trade and foreign direct investment, foreign direct investment has a more significant impact on industrial competitiveness. In order to further enhance the industrial competitiveness of Guangzhou, promote the continuous optimization of the industrial structure of Guangzhou, and highlight the supporting and leading role of high-level opening up to the development of Guangzhou's industry, the following policy recommendations are proposed:

\subsection{Optimize the foreign investment environment and promote continuous industrial transformation and upgrading}

Guangzhou should further optimize the investment environment, simplify the procedures for foreign-invested service industry project applications and high-tech products tariff-free procedures, and help enterprises enjoy policy convenience through linkages between upper and lower levels and departmental cooperation, establish a fair and predictable policy environment, and improve investment promotion "Guangzhou Temperature" creates a policy atmosphere for foreign-invested enterprises to develop in Guangzhou.

\subsection{Vigorously develop the productive service industry}

Guangzhou must further deepen reform and opening up, relax market access, simplify approval procedures, improve investment facilitation in the producer servi ce industry, encourage domestic and foreign capital $t$ o participate in the development of the producer serv ice industry, and enhance Guangzhou's industrial com petitiveness. In this process, it is necessary to rely $\mathrm{m}$ ore on the power of innovation-driven and market $\mathrm{m}$ echanisms to guide foreign investment to focus on $\mathrm{pr}$ oduction services such as R\&D and design, business services, marketing, and after-sales services to create a new engine for the development of Guangzhou's in dustry.

\subsection{Increase the opening up of high-end manufacturing}

Guangzhou should continue to deepen the reform of the system and mechanism of opening to the outside world, strengthen the awareness of actively serving enterprises, and strive to reduce the operating costs of enterprises. Guangzhou should take the construction of the Guangdong-Hong Kong-Macao Greater Bay Area as an opportunity to attract investment around the "strategic industrial chain", increase the opening up of high-end manufacturing, create an internationally competitive investment environment, and promote the formation of a new pattern of comprehensive opening up in Guangzhou.

\subsection{Further increase the degree of opening up}

Guangzhou should actively strengthen regional econo mic cooperation, gradually liberalize trade protection barriers, improve the convenience and freedom of for eign trade, and expand economic and trade cooperatio $\mathrm{n}$ with other countries, especially Southeast Asian co untries. Guangzhou should seize the historical opportu nity of the Guangdong-Hong Kong-Macao Greater Ba $\mathrm{y}$ Area and unswervingly promote a new round of $\mathrm{o}$ pening-up with the "Belt and Road" as the main li ne and the free trade zone strategy and regional econ omic cooperation strategy as the important support. 


\subsection{Promote the upgrading of industrial structure through industrial clusters}

To cultivate industrial clusters in Guangzhou, it is ne cessary to make a development plan based on the in dustrial development environment and industrial found ation, focus on the established leading industries to at tract investment, enlarge the scale of leading industrie $\mathrm{s}$, and implement value chain investment promotion. At the same time, it studies the development of leadi ng industries in the region, introduces targeted produc tion links that are missing locally, and continuously i mproves the industrial development environment in $G$ uangzhou.

When Guangzhou is accelerating its opening to th e outside world and realizing that the industry is mo ving to the top of the global value chain, on the one hand, it should improve the innovation capabilities o f local service departments, strengthen industrial integ ration, and enhance the development level of Guangz hou' s high-end manufacturing industry; on the other hand, it should improve the quality of education and encourage professional training Develop, promote the flow of production factors, avoid the shortage of tale nts in the high-end service industry, and promote the upgrading of Guangzhou' s industrial structure.

\section{REFERENCES}

1. F.De Leeuw, et al.Urban Air Quality in Larger C onurbations in the European Union[J]. Environme ntal Modelling and Software, 2001,16(4).

2. W.W.Ren, et al.Urbanization, Land Use, and Wat er Quality in Shanghai:1947-1996[J].Environmen t International, 2003,29(5).

3. Rodrik,Dani.What's So Special about China's Exp orts?[J].China and World Economy,2006,14(5):1-1 9.

4. Tian Yinhua,Kuang Change. An Empirical Study on the Relationship between Industrial Structure Upgrading and Economic Growth in Hunan Provi nce-Based on the data from 1978 to 2012 [J]. Journal of Xiangtan University: Philosophy and S ocial Sciences Edition,2014(6):50-58.

5. Huang Qinbo,Fan Houming. Foreign trade, econo mic growth and industrial structure upgrading [J]. International trade issues,2010(2):38-44.

6. Fu Qiang,Li Xiuxiu. Trade openness, industrial st ructure upgrading and economic growth $[\mathrm{J}]$. Indus trial Technology Economy,2014(3):115-120.

7. Zhang Liguang,Shi Youjun,Li Hua. The long-term equilibrium effect of trade openness on economi c growth [J]. Financial Science,2004(1):78-82.

8. Zhao Wei. From Internationalization to Regionaliz ation or from Regionalization to Internationalizati on: Comparison between the Opening Ways of th e Two Great Deltas during Their Economic Tran sition. [J]. Zhejiang Social Sciences, 2002 (2) : 54-60.
9. Konan, D.E., Maskus, K.E., Quantifying the Impa ct of Services Liberalization in a Developing Co untry[J].Social Science Electronic Publishing, 200 4 (1) :142-162.

10. Ishikawa, J., et al., FDI in post-production servic es and product market competition[J].Journal of I nternational Economics, 2010 (6) :73-84. 